


\title{
Legal regulation of payment systems in Ukraine: current situation and the prospects for development
}

\author{
DOI: https://doi.org/10.46398/cuestpol.3969.28
}

\author{
Taras Protsenko * \\ Sobol Yevhen ** \\ Yerpyntsev Pylyp *** \\ Koshchynets Viktor **** \\ Anheleniuk Anna-Maria *****
}

\section{Abstract}

The purpose of the article is to consider the main international regulations on the introduction and operation of payment systems in Europe, as well as national legislation providing for the development of payment systems in Ukraine. The research methodology includes the following general and special legal methods: axiological, historical and legal, formal and logical, comparative and legal, as well as the methods of analysis and synthesis, induction and deduction, summarization. Results of the research. The main international regulations on the formation and functioning of payment systems in the European countries, which became the basis for the development of relevant legislation of Ukraine in this area, are analyzed. The legal acts that currently regulate this issue in our country are considered, as well as Draft Laws aimed at resolving existing problematic issues in the payment systems market are examined. Practical meaning. The positive dynamics of the development of the Ukrainian payment legislation in accordance with the needs of the market and changes in the payment habits of the population are established. Value / originality. Emphasis is placed

* Doctor of Juridical Sciences, Professor, Chief Researcher of the Research Laboratory of Criminological Research and Problems of Crime Prevention of the State Research Institute of the Ministry of Internal Affairs of Ukraine, Ukraine. ORCID ID: https://orcid.org/oooo-0oo3-0611-5258. Email: dndi@mvs. gov.ua

** Doctor of Law, Professor, Head of the Department of State Legal Disciplines and Administrative Law of Volodymyr Vynnychenko Central Ukrainian State Pedagogical University, Ukraine. ORCID ID: https://orcid.org/oooo-0002-0804-8354. Email: @cuspu.edu.ua

*** Vice-principal of Donetsk Law Institute Yeprintsev Philip Serhijovich, Candidate of Law ORCID ID: https://orcid.org/oooo-0002-9790-9565. Email postmaster@dki.donetsk.ua

**** Doctor of Law, Associate Professor, Professor of the Department of Legal Psychology of the National Academy of Internal Affairs, Ukraine. ORCID ID: https://orcid.org/oooo-00o2-3694-4586. Email: k015@naiau.kiev.ua

***** PhD in Law, Researcher of the 3rd NDV NDL on the problems of legal and organizational support activities for the Ministry of the State Research Institute of the Ministry of Internal Affairs of Ukraine. ORCID ID: https://orcid.org/oooo-0001-5947-5105. Email: AnheleniukA-M@ukr.net. 
on the need for the further measures by the National Bank of Ukraine in order to harmonize national legislation with the European regulations in this area.

Keywords: payment systems; payment services; payment legislation; payment directives; non-cash payments.

\section{Regulación legal de los sistemas de pago en Ucrania: situación actual y perspectivas de desarrollo}

\section{Resumen}

El propósito del artículo es considerar las principales regulaciones internacionales sobre la introducción y operación de sistemas de pago en Europa, así como la legislación nacional que prevé el desarrollo de sistemas de pago en Ucrania. La metodología de investigación incluye los siguientes métodos legales generales y especiales: axiológico, histórico y legal, formal y lógico, comparativo y legal, así como los métodos de análisis y síntesis, inducción y deducción, resumen. Se analizan las principales regulaciones internacionales sobre la formación y funcionamiento de sistemas de pago en los países europeos, que se convirtieron en la base para el desarrollo de la legislación pertinente de Ucrania en esta área. Se consideran los actos jurídicos que actualmente regulan este tema así como se examinan los Anteproyectos de Ley dirigidos a resolver las problemáticas existentes en el mercado de los sistemas de pago. Se establece la dinámica positiva del desarrollo de la legislación de pagos de Ucrania de acuerdo con las necesidades del mercado y los cambios en los hábitos de pago de la población. A modo de conclusión se hace hincapié en la necesidad de que el Banco Nacional de Ucrania adopte nuevas medidas para armonizar la legislación nacional con la normativa europea.

Palabras clave: sistemas de pago; servicios de pago; legislación de pagos; directivas de pago; pagos no monetarios.

\section{Introduction}

Payment systems are an important component of the stable functioning of the State's financial system and its economy as a whole. The development of payment systems around the world has been characterized by a rapid reduction in the use of cash and paper payment documents, the transition to new payment instruments and modern payment technologies in recent 
Taras Protsenko, Sobol Yevhen, Yerpyntsev Pylyp, Koshchynets Viktor y Anheleniuk AnnaMaria

years. Besides, payment systems are an element of the e-commerce infrastructure, which has been developing rapidly both around the world and in Ukraine. Thus, electronic payments using payment systems are becoming more common in Ukraine and are steadily increasing their share in the payments segment.

Dynamic development of payment systems plays an important role in the formation of new mechanisms for the functioning of the country's payment infrastructure, the emergence of new types of payment instruments, as well as the forms of settlements execution, significantly affects all spheres of society, while contributing to or inhibiting stable economic growth. Given this, it is important to consider the current development of payment systems in our country, to conduct the analysis of their reliability, which can ensure financial security of the customers and economic security of Ukraine's economy as a whole, as well as the prospects for the further operation taking into account the challenges of our time (Dzhusov and Piliak, 2020: 196).

At present, Ukraine is gradually moving to the non-cash form of payment, although it still has a high ratio of cash to GDP in most developed countries, which is influenced by a number of negative factors such as high level of underground economy and low confidence in financial institutions. There is also a lack of public awareness of the benefits of non-cash payments, accompanied by a still high level of distrust in their use. Therefore, the low level of use of non-cash payments, underdeveloped financial infrastructure, the habits of the population that hinder the development of payment systems are among the key problems of Ukraine's payment systems nowadays.

The purpose of the article is to consider the main international regulations on the introduction and operation of payment systems in Europe, as well as national legislation providing for the development of payment systems in Ukraine.

\section{Methodology}

The methodology of the article is based on general and special methods of scientific knowledge, the use of which is determined by the purpose, object and subject of research. In particular, the axiological method was used to substantiate the importance of international and domestic regulations in the formation and development of the payment systems in Ukraine. The method of hermeneutics was applied in the process of studying international and domestic legal acts (as well as their drafts), governing the issue, with their further interpretation. Historical and legal method allows to trace the historical development of the studied phenomena. Formal and logical (dogmatic) method allowed to outline the range of circumstances that affect the formation of the existing payment systems in Ukraine. 
The method of analysis and synthesis helped to clarify the content of the legal mechanism of functioning of payment systems. The method of induction and deduction allowed to determine the directions of improvement of the payment legislation of Ukraine taking into account the challenges of the time and its harmonization with European legislation. The legal and comparative method was used to compare the state of development of payment systems in Ukraine and some countries of the European Union. With the help of the method of summarization the relevant conclusions and suggestions were drawn.

\section{Literature Review}

The formation and development of modern payment systems have been the subject of research by many foreign and domestic scholars.

Thus, Santiago Carbó-Valverde and Charles M. Kahn (2016) studied the current state and prospects of payment systems in Europe and the United States. They pointed out that the existing differences in the regulation of payment systems are the result of different initial conditions and, consequently, they need different solutions to overcome technological challenges. Thus, if the way to unify the payment market and payment instruments in Europe was the introduction of a single payment zone of the European Union in euros (SEPA), the United States did not have a single comprehensive system program to regulate payment systems. In the course of the study, the authors found that the formation and development of payment systems is significantly influenced by the relevant legal acts. However, while European countries have developed unified regulatory framework in order to establish uniform standards for the development of payment systems, the United States is still having problems with the application of unified solutions to control the payment services market.

Inna Oliinyk and William Echikson (2018) conducted a thorough study of the so-called "payment revolution" in Europe resulting from the adoption of the payment directives. They analyzed payment innovations in the process of protecting the privacy of consumers of payment services. In particular, the latter drew attention to the fact that in order to comply with these directives, the banks need to upgrade the existing systems of security measures through the introduction of new IT technologies. Although the Directive provides easy and secure access to a wide range of payment services for the consumers, a number of issues remain unresolved (the problems with the access to the Application Programming Interface (API), whether individuals and small businesses will receive appropriate protection, etc.). 
Taras Protsenko, Sobol Yevhen, Yerpyntsev Pylyp, Koshchynets Viktor y Anheleniuk AnnaMaria

450

Legal regulation of payment systems in Ukraine: current situation and the prospects for development

Inna Romanova, Simon Grima, Jonathan Spiteri, and Marina Kudinska (2018), having studied the importance of the payment directives noted that their implementation in payment legislation will promote competitiveness in the payment services market, innovation and its development in general. Thus, despite the possible risks associated with the implementation of their provisions, the high speed of payment transactions and security and confidentiality remain a priority. Providing access to the payment services market to non-financial companies will make adjustments and promote competitiveness among traditional financial service providers and banks.

Raynor de Best (2021) studied common payment methods in different European countries, determining that each country of the Eurozone has its own most popular payment systems, which are evolving in line with market trends and demands of the population. It is also noted that such powerful payment systems as Visa and Mastercard were not leading in all countries of the continent. For example, in 2018, MasterCard had a 95\% market share in the Netherlands, but was $12 \%$ of the German market. In Belgium, an internal solution called Bancontact was much more popular than Visa or Mastercard. In short, the European payment market is fragmented and heterogeneous.

However, these works do not pay enough attention to the study of the dynamics of the main indicators of development of this part of the financial system and its impact on other areas of activity, as well as the consideration of existing problems and prospects for payment systems in Ukraine resulting in the relevance of this study.

\section{Results and Discussion}

Article 1 of the Law "On Payment Systems and Money Transfer in Ukraine" (Law No. 2346-III, 2001) defines the payment system as the payment organization, participants in the payment system and the set of relations that arise between them during the money transfer. It is enshrined that the money transfer is a mandatory function to be performed by the payment system. The legislator divides payment systems into domestic (in which the payment organization is resident and which carries out its activities and ensures the transfer of funds exclusively within Ukraine) and international ones (payment system in which the payment organization can be both resident and non-resident and which carries out its activities in two or more countries and ensures the transfer of funds within this payment system, including from one country to another).

The purpose of creating payment systems is obvious - to reduce the cash supply and, accordingly, to minimize the cost of issuing cash and reduce the cost of its maintenance, collection, and re-calculation. Besides, the payment 
systems guarantee the smooth operation of all elements of the system itself, ensure the security of transactions, insure against any disruption of financial transactions. Given the intensification of globalization and the implementation of European integration measures, in particular for Ukraine, the issue of acquiring an internal market regime with the European Union in the area of financial services, including payment ones, is relevant.

In view of the above, it will be appropriate to determine the most important stages in the formation of legal regulation of payment service providers and the functioning of payment systems in the EU Member States. The process of unification began with the creation of the Single Euro Payments Area (SEPA) in 2007, which is characterized by the complete elimination of the difference between internal and external payments in euros, which speeds up monetary transactions. The SEPA implementation process was completed in 2014 (Deloitte, 2017).

The next significant step was the adoption in 2007 the Payment Services Directive 1 - PSD1 (Directive of the European Parliament and of the Council, 2007) on payment services in the internal market. This Directive laid down the principles for the provision of payment services, the procedure for supervision and special payment instruments, etc. Following the adoption of the Payment Services Directive 1, the process of digitalization of the European economy was launched, which gave impetus to the creation of new products and accelerated online payments. However, most new companies did not control the implementation of this Directive, which hindered the further development of the payment services market.

Thus, in 2009 the Directive № 2009/110 / EC (Directive of the European Parliament and of the Council, 2009) was fully adopted. It was this Directive that included the rules for the conversion of electronic money, as well as the requirements for the establishment, implementation and prudential supervision of the activities of electronic money institutions.

Particular attention should be paid to the Second Payment Services Directive 2015/2366 / EC (Payment Services Directive 2 - PSD2) (Directive of the European Parliament and of the Council, 2015), which was developed and adopted in 2015 to improve the protection of both customers and payment services in general, to promote competitive environment and develop innovation in this area. PSD 2 introduced two new forms of payment agents to the payment services market, namely the payment service providers (PISPs) and payment organizations (AISPs). This Directive also made adjustments to the procedure for ensuring the security of users during payment transactions empowered the European Banking Association (EBA) to develop requirements for security of transactions and the methods of correct authentication of the users. The Directive further applies the rules for the provision of SEPA Direct Debit and SEPA Credit Transfer technologies, within the rulebooks, which are based on the XML 
Taras Protsenko, Sobol Yevhen, Yerpyntsev Pylyp, Koshchynets Viktor y Anheleniuk AnnaMaria

protocol (messaging) ISO 20022 (Husiev and Kim, 2017). Besides, the Directive guarantees free access to the European market to various payment systems, including non-bank payment services, which can perform money transfers not only through banks but also through various paying agents, telecommunications networks and information technology operators. All this promotes competition and development of innovations in the area of financial technologies, as well as the free exercise by the client (user, consumer) of their right to choose the most acceptable payment service, which will generally affect the competitiveness of European banks and payment companies in the global electronic payment network.

It is worth noting that the Payment Services Directive 2, which regulates payment systems in Europe, is considered much more effective than similar initiatives in the US, and therefore the global impact of the SEPA legal framework on regulating the payment services market (Valverde \& Kahn 2016).

Although, Romanova et al., (2018) note that based on the analysis of the latest trends in FinTech, Payment Services Directive 2 creates additional risks and security responsibilities for the financial services and banking sectors, consumer data protection, and does not exclude certain reputational risks connected with the opening of the market for nonfinancial institutions. Another risk of the Directive is a potential security risk in data exchange with the Third Party Payment Providers, as well as the associated reputational risks and "grey areas" of liability for any data breaches by the third party.

However, the above-mentioned changes in European legislation have not bypassed our State. The borrowing of European experience in regulating the payment sector and the desire to meet European standards for further integration into the EU is reflected in the activities of the National Bank of Ukraine, which implements measures to harmonize national payment legislation with the European one in accordance with the Association Agreement with the EU. As Avdeev et al. (2019) correctly pointed out in the context of the globalization of international life, one of the key areas for the progressive and fruitful development of international relations is the integration of the legislation of States to ensure economic security.

The key factor influencing the development of payment systems in Ukraine is the activity of the National Bank of Ukraine, focused on effective and continuous operation of the payment mechanism - oversight of payment systems. Such activities are regulated by the relevant Regulation on the supervision (oversight) of payment systems and settlement systems in Ukraine, which is based on the European standard on the supervision (oversight) of payment systems and settlement systems (The Eurosystem's oversight) (Resolution of the Board of the National Bank of Ukraine, 2014). 
The supervisory function is defined in the Treaty on the Functioning of the European Union and the Statute of the European System of Central Banks (ESCB) and the European Central Bank (ECB) as facilitating the smooth operation of payment systems and ensuring their efficiency and security. In turn, the National Bank of Ukraine developed "Guidelines for risk management in payment systems" (National Bank of Ukraine, 2018), which provides a clear delineation of payment system risks (legal risk, operational risk, credit risk, liquidity risk, systemic risk), and developed a so-called profile for each of them (source, location, form of implementation, assessment of the possibility and consequences of relevant risks).

Characterizing the current state of payment systems in Ukraine, it is necessary to analyze the data of the annual Report on the oversight of payment systems, which is formed by the National Bank of Ukraine. According to the Report of 2019 (National Bank of Ukraine, 2019), the structure of the payment systems market in Ukraine includes public payment systems (created by the National Bank of Ukraine) and private ones (created by residents and non-residents). As of the end of 2019, 46 domestic and international payment systems created by the residents and non-residents were registered in Ukraine, as well as two systems created by the National Bank (Electronic Payment System of the National Bank (EPS) and National Payment System "PROSTIR"). The total number of participants in payment systems (excluding EPS) was 128 financial institutions, including 69 banks and 59 non-bank financial institutions. According to the results of 2019, EPS remained the only systemically important payment system in Ukraine.

The category of socially important payment systems includes five payment systems - "MasterCard" (MasterCard International Incorporated, USA); Visa (Visa International Service Association, USA); Western Union (Western Union Financial Services Inc. USA / Western Union Network, SAS, France); NovaPay (Post Finance LLC); "Postal transfer" (PJSC "Ukrposhta").

The category of important payment systems includes six more payment systems - "Financial World" (LLC "Ukrainian Payment System"); MoneyGram (Money Gram Payment Systems Inc. USA); City 24 (Phoenix Financial Company LLC); "FLASHPAY" (PJSC "Family Bank"); RIA (Continental Exchange Solutions Inc, USA); "INTELEXPRESS" (JSC Microfinance Organization "Intellexpress", Georgia) (National Bank of Ukraine, 2019).

If we characterize the market of payment systems in some European countries, we can note that one of the most common payment systems is also "MasterCard" (MasterCard International Incorporated, USA) and Visa (Visa International Service Association, USA). However, the market for payment services is heterogeneous and each country has its own features, which determines the introduction and operation of different 
Taras Protsenko, Sobol Yevhen, Yerpyntsev Pylyp, Koshchynets Viktor y Anheleniuk AnnaMaria

payment systems. For example, the most popular way to make payments in Belgium is Bancontact, SEPA and Sofort are also popular. Cartes Bancaires dominates the payment environment in France, and most French cards are Cartes Bancaires, together with Visa or Mastercard. Germany is one of the most fragmented markets when it comes to payment methods. Most online payments use payment methods such as SEPA Direct Debit, SOFORT and Giropay. Popular method of payment in retail is an invoice; the third party pays for goods and services, and then charges the buyer after delivery. Popular payment methods in Italy are American Express; Ewallets; Mastercard; Visa; Klarna Pay Over time. In Poland, internet banking known as Pay-by-links is the most popular payment method and accounts for $75 \%$ of all electronic payments.

MultiBanco, which accounted for about $85 \%$ of total sales, is the most popular payment system in Portugal. This is a post-pay option, when the link is generated at the time of payment and is paid later through an ATM using a debit card or through Internet banking. Cash is still the most popular payment method in Spain, and the number of ATMs per million inhabitants is one of the highest in Europe. Cards are also popular as more than 85\% of the population have at least one Visa or Mastercard debit or credit card. Buyers in the UK are the world leaders in terms of online shopping, and debit cards for non-cash payments are popular (the average buyer owns 2-3 bank cards). Cards account for about 90\% of all online payments, another popular option is digital wallets, and online banking is virtually non-existent. Popular payment methods in the UK: Visa; Mastercard; BACS Direct Debit; Digital wallets; American Express; Klarna Pay Later) (National Bank of Ukraine, 2020a).

According to the results of monitoring in 2019, the important operators of payment infrastructure services in Ukraine are PJSC "Ukrainian Processing Center" and LLC "TAS LINK". The National Bank of Ukraine has established strict requirements for ensuring the continuity of activities based on international oversight standards for such significant operators of payment infrastructure services. The Resolution "On Approval of Amendments to the Regulations on Supervision (Oversight) of Payment and Payment Systems in Ukraine" (Resolution of the National Bank of Ukraine, 2020) further established the procedure and criteria for determining important operators of payment infrastructure services.

It is worth noting that at the end of 2018, the world's largest (by the number of issued payment cards) international payment system UnionPay International entered the Ukrainian market. Besides, such giants as GooglePay and ApplePay have also shown interest in Ukraine due to the active development of contactless payment technology. PayPal payment systems are among the available payment systems in Ukraine (however, only one of the payment system's options is available to Ukrainians - to 
spend money from your account but not receive it) and AVERS №1 (Uteka, 2018).

The introduction of the IBAN was also an important step in Ukraine, which is the result of the implementation of the Payment Services Directive 2 in the national legislation. The Resolution no. 118 (National Bank of Ukraine 2018) enshrined that the international bank account number is mandatory for customers of all Ukrainian banks when money transferring in both national and foreign currency. This made it easier to identify the payer and the recipient of the funds, as well as provide information about the IBAN using a QR code. This number is 29 letters and numbers for Ukraine (includes the country code, control digit, bank code and account number).

A positive trend for Ukraine is the increase in the share of noncash transactions over the past 5 years. Modern payment systems allow consumers to make money transfers, make settlements in the payment terminals of trade and service enterprises by using the Internet access and bankcard number to buy goods, pay for services; the sellers, in turn, can safely check and receive payments instantly.

Now let us turn to the experience of European countries on this issue. The study conducted in 2019 indicates that Iceland, Sweden, Norway, Denmark and the United Kingdom were the countries with the lowest levels of cash use (payments were made, in particular, by using debit cards). Digital wallets, such as Apple Pay or Google Pay, were the least popular payment option in 2019 in such countries as France, Germany, Italy, Poland, Sweden and the United Kingdom. This is a marked difference from, for example, China or the United States. One reason for this may be that some countries have adopted contactless options on debit cards. The market share of contactless payments in various European countries was, for example, $83 \%$ in Poland and $50 \%$ in Italy. There is also a significant impact of services provided on the Internet on the development of cashless payments in the future (Raynor de Best, 2021).

Recent events (such as the pandemic and quarantine restrictions) have made adjustments to the payment habits of Ukrainian citizens towards non-cash payments, including on the Internet. The total number of transactions (non-cash and cash) using payment cards issued by Ukrainian banks in the first nine months of 2020 amounted to 4310.2 million items, and their amount was UAH 2,807.9 billion. The number of these transactions increased by $18.0 \%$, and the amount - by $8.7 \%$ compared to the same period in 2019. This is primarily due to the increase in the amount and number of non-cash transactions - their share predominates in the total amount of payment card transactions. Thus, the amount of noncash transactions amounted to UAH $1,550.1$ billion or $55.2 \%$ of the sum of all card transactions in 2020, compared to $49.7 \%$ in 2019 (for the first 9 
Taras Protsenko, Sobol Yevhen, Yerpyntsev Pylyp, Koshchynets Viktor y Anheleniuk AnnaMaria

months). At the same time, the number of transactions for withdrawal from payment cards decreased by $11.3 \%$, and the amount - by $3.3 \%$ compared to the first 9 months of 2019. The total number of issued payment cards in Ukraine as of October 1, 2020 amounted to 73.4 million units. This is $7.4 \%$ more than in January 2020. The payment infrastructure continued to expand steadily during the first 9 months of 2020. The number of business entities accepting payment cards increased by a third (by 31.7\%) during this period - to almost 316.4 thousand (National Bank of Ukraine, 202ob). Thus, the increase in the number of non-cash payments, including using payment cards, necessitates further improvement in the area of payment services.

To this end, the National Bank of Ukraine in 2020 began work aimed at updating the payment legislation, which will ensure the process of market recovery and increase public confidence in payment systems. Thus, based on the need for regulation of innovative payment services and the implementation of European regulations, in particular Payment Services Directive 2, Electronic Money Directive (EMD), the Verkhovna Rada of Ukraine registered the Draft Law 644364 on payment services (Draft law of Ukraine No. 4364, 2020). It envisages a number of key changes in the payment services market, in particular: defining the range of payment service providers; establishing requirements for the authorization of payment service providers and introducing the possibility of creating and operating small payment institutions with simplified requirements for them; granting permission to non-banking financial institutions to carry out payment transactions without mandatory participation in payment systems; granting the right to issue electronic money and payment cards not only to banks, but also to other payment service providers that have received the appropriate license; creating the basis for the introduction of "open banking" in the payment infrastructure of Ukraine; ensuring the possibility of opening and maintaining payment accounts by nonbank payment service providers; strengthening measures to protect the customers' rights, in particular in order to minimize cyber fraud, increase liability for illegal actions with payment instruments and means of access to bank and / or payment accounts, etc.; increasing the requirements for the security of payment transactions, in particular regarding the need for payment service providers to use enhanced user authentication in certain cases.

As already mentioned, strengthening measures aimed at protecting the rights of payment system users is one of the areas in the process of updating national payment legislation. Given the latest global trends related to the development of Internet services, as well as the mass transition of users of payment services online, the National Bank of Ukraine plans to increase information security and cyber security in the area of money transfer. In particular, the regulator intends to set clear requirements for 
payment market participants to build a system of information protection and cybersecurity, as well as regulation of the procedure for detecting cyber-attacks that reduce the reliability of payment systems. The relevant innovations are outlined in the Resolution of the National Bank of Ukraine on the Approval of the Regulation "On information protection and cyber protection in payment systems" (Resolution of the Board National Bank of Ukraine, 2021).

It is worth noting that according to the provisions of the Payment Services Directive 2, there are two options for data protection of the customers of payment services: 1) to allow third parties to identify themselves; or 2) to provide access through a separate interface, for example through the application programming interface ("Application Programming Interface API"). Otherwise, a fall-back mechanism should be used. Such an interface should be standardized and include a set of requirements that the software of one company can be used to communicate with the software of another one. Banks will use the APIs and customer authentication will remain mandatory. The proponents of the API insist on the effectiveness of this security system for users of the payment services market. For example, as part of the implementation of the Directive, it is planned to provide a common API platform for access and protection of payment data. The Berlin Group, as an independent coalition of 25 players in the payment services market from 10 Eurozone countries, has developed common API standards. Some other similar European initiatives in this area exist in other countries - the Polish API and STET in France. Probably the most important and influential is the API initiative in the UK, called Open Banking. It provides joint APIs for the country's nine largest banks (Oliinyk and Echikson, 2018).

In view of the above, transforming the national payment legislation in order to comply with the Payment Services Directive 2 should also take into account the experience of other European countries in implementing measures to ensure the protection of confidentiality and security of payment market participants.

Besides, the National Bank of Ukraine continues to modernize the Electronic Payment System of the National Bank (hereinafter - EPS) and the payment infrastructure of Ukraine in accordance with global trends, as well as the requirements of the time and business. In particular, in 2021 the regulator plans to work on the transition of banks to the international standard ISO20022, which will ensure further automation of payment transactions at a qualitatively new level. Among the main advantages of using the international standard ISO 20022 in the payment infrastructure of Ukraine are: harmonization of the Ukrainian payment market with the world one; emergence and operation of new payment market players and payment instruments in accordance with the Second EU Payment 
Taras Protsenko, Sobol Yevhen, Yerpyntsev Pylyp, Koshchynets Viktor y Anheleniuk AnnaMaria

Directive (PSD2); introduction of new and expansion of the functional content of existing payment instruments for the benefit of banks and their customers; implementation of new automated processes that cover the full life cycle of payments; increasing the level of providing services, efficiency and transparency of payments; expansion of payment details due to the necessary additional information; strengthening information security (National Bank of Ukraine, 2021).

\section{Conclusion}

Given the above, we can summarize that at the present stage of development of the payment systems market in Ukraine there is a positive trend due to the expansion of services provided, integration of payment system infrastructure of various types, the spread of modern security technologies for payment system users (including biometric user authentication technologies). Besides, systematic measures are being taken to improve the legal regulation of relations in the area of payment systems and harmonize national legislation with European legislation in order to ensure further effective cooperation in this area.

However, despite the generally stable development of payment systems in Ukraine, there are a number of problems that need to be addressed. Thus, international payment systems have an advantages in the domestic market, with which it is difficult for national agents to compete. Therefore, it is necessary to stimulate and support national enterprises in the creation of domestic payment systems and related services by providing benefits (tax or credit) for residents who wish to open their business in this area.

Payment systems play one of the most important roles in the modern economy - they are a guarantee of stable operation of both the banking system and the economy as a whole. In addition, significant money amounts are transferred with the help of individual payment systems, so violations in their work can cause systemic risks and negatively affect not only financial stability but also the overall economic security of the State. That is why the rational organization of their work will contribute to the smooth functioning of the financial sector of the country as a whole and accelerate the implementation of payments in international and national directions.

\section{Bibliographic References}

AVDEEV, Vadim; AVDEEVA, Olga; ROZENKO, Stanislav; FEDULOV, Igor; KULESHOV, Igor; KOSARENKO, Nikolay. 2019. "The Main Directions 
of Integration of States' Activities to Ensure Economic Security" In: Amazonia Investiga. Vol. 8, No. 24, pp. 14-22. Available online. In: https://amazoniainvestiga.info/index.php/amazonia/article/view/945. Consultation date: 28/11/2020.

DE BEST, Raynor 2021. Payments in Europe - statistics \& facts. Available online. In: https://www.statista.com/topics/3946/digital-paymentmethods-in-europe/. Consultation date: 28/03/2021.

DELOITTE. 2017. "How to flourish in an uncertain future. Open banking and PSD2". Available online. In: URL: https://www2.deloitte.com/content/ dam/Deloitte/uk/Documents/financial-services/deloitte-uk-openbanking-how-to-flourish-in-an-uncertain-future.pdf. Consultation date: 28/03/2021.

DIRECTIVE (EU). 2015. 2015/2366 of the European Parliament and of the Council of 25 November 2015 on payment services in the internal market, amending Directives 2002/65/EC, 2009/110/EC and 2013/36/EU and Regulation (EU) No 1093/2010, and repealing Directive 2007/64/ EC. Available online. In: https://eur-lex.europa.eu/legal-content/EN/ TXT/?uri=celex\%3A32015L2366. Consultation date: 28/03/2021.

DIRECTIVE. 2007. 2007/64/EC of the European Parliament and of the Council of 13 November 2007 on payment services in the internal market amending Directives 97/7/EC, 2002/65/EC, 2005/60/ECand 2006/48/ EC and repealing Directive 97/5/EC. Available online. In: https://eurlex.europa.eu/legal-content/EN/ALL/?uri=CELEX:32007Loo64. Consultation date: $28 / 03 / 2021$.

DIRECTIVE. 2009. 2009/110/EC of the European Parliament and of the Council of 16 September 2009 on the taking up, pursuit and prudential supervision of the business of electronic money institutions amending Directives 2005/60/EC and 2006/48/EC and repealing Directive 2000/46/EC(Text with EEA relevance).Available online. In: https://eurlex.europa.eu/legal-content/en/TXT/?uri=CELEX\%3A32009L0110. Consultation date: $28 / 03 / 2021$.

DRAFT LAW OF UKRAINE. 2020. No. 4364. Official Web site of the Verkhovna Rada of Ukraine, November 12, 2020. Available online. In: http://w1.c1. rada.gov.ua/pls/zweb2/webproc4_1?pf3511=70412. Consultation date: 28/03/2021.

DZHUSOV, Alexey; PILYAK, Alexander. 2020. "Current state, problems and prospects of development of payment systems in Ukraine". In: Economic space. No. 154, pp. 190 - 196. 
Taras Protsenko, Sobol Yevhen, Yerpyntsev Pylyp, Koshchynets Viktor y Anheleniuk AnnaMaria

460

Legal regulation of payment systems in Ukraine: current situation and the prospects for development

HUSIEV, Daniel; KIM, Boris. 2017. PSD2 in the European payment services market: historical and legal analysis of the adoption of the Directive. In: PLUS Magazine "Expert Opinions". Available online. In: https://plusworld. $\mathrm{ru} /$ professionals/psd2-na-rynke-platezhnyh-servisov-evropy-istorikopravovoj-analiz-prinyatiya-direktivy/. Consultation date: 28/03/2021.

NATIONAL BANK OF UKRAINE. 2018. Guidelines for risk management in payment systems. Available online. In: https://bank.gov.ua/ua/news/ all/metodichni-rekomendatsiyi-z-upravlinnya-rizikami-v-platijnihsistemah. Consultation date: 28/03/2021.

NATIONAL BANK OF UKRAINE. 2019. Report on the oversight of financial market infrastructures for 2019. Available online. In: https://bank.gov. ua/ua/news/all/zvit-z-oversayta-infrastruktur-finansovogo-rinku-za2019-rik. Consultation date: 28/03/2021.

NATIONAL BANK OF UKRAINE. 2020a. The list of systemically important, socially important and important payment systems in Ukraine is determined. Available online. In: https://bank.gov.ua/ua/news/all/ viznacheno-perelik-sistemno-vajlivih-sotsialno-vajlivih-ta-vajlivihplatijnih-sistem-v-ukrayini. Consultation date: 28/03/2021.

NATIONAL BANK OF UKRAINE. 2020b. Undisputed trends in the card market in 2020 - online payments and contactless payments. Available online. In: https://bank.gov.ua/ua/news/all/bezzaperechni-trendi-kartkovogorinku-u-2020-rotsi--rozrahunki-v-interneti-ta-bezkontaktni-plateji. Consultation date: $28 / 03 / 2021$.

NATIONAL BANK OF UKRAINE. 2021. The transition of the payment infrastructure to the international standard ISO20022 will be as comfortable as possible for the banks. Available online. In: https://bank. gov.ua/ua/news/all/perehid-platijnoyi-infrastrukturi-na-mijnarodniystandart-iso20022-bude-maksimalno-komfortnim-dlya-bankiv. Consultation date: 28/03/2021.

OLIINYK, Inna; ECHIKSON, William. 2018. "Europe's Payments Revolution Stimulating Payments Innovation while Protecting Consumer Privacy". In: CEPS Research Reports, no. 2018/o6. Available online. In: https:// www.ceps.eu/wp-content/uploads/2018/o9/RR2018_06_Europes\%20 Payments\%20Revolution.pdf. Consultation date: 28/03/2021.

ROMANOVA, Inna; GRIMA, Simon; SPITERI, Jonathan; KUDINSKA, Marina. 2018. "The Payment Services Directive II and Competitiveness: The Perspective of European Fintech Companies”. In: European Research Studies Journal. Vol. XXI, Issue 2, pp. 3-22. Available online. In: DOI: 10.35808/ersj/981. Consultation date: 28/03/2021. 
UKRAINE. 2001. Law No. 2346-III of April 05, on payment systems and money transfer in Ukraine. Official Gazette of the Verkhovna Rada of Ukraine of April, 2001, no. 29, p. 137.

UKRAINE. 2014. Resolution of the Board of the National Bank of Ukraine 755 of November 28, 2014, on approval of the Regulation on supervision (oversight) of payment systems and settlement systems in Ukraine. Official Web site of the National Bank of Ukraine. Available online. In: https://zakon.rada.gov.ua/laws/show/v0755500-14\#Text.Consultation date: $28 / 03 / 2021$.

UKRAINE. 2018. Resolution of the Board of the National Bank of Ukraine 162, of December 28, 2018, on the introduction of an international bank account number (IBAN) in Ukraine. Official Web site of the National Bank of Ukraine. Available online. In: https://zakon.rada.gov.ua/laws/ show/v0162500-18\#Text. Consultation date: 28/03/2021.

UKRAINE. 2020. Resolution of the Board of the National Bank of Ukraine 11, of January 21, 2020, on approval of the Amendments to the Regulations on supervision (oversight) of payment systems and settlement systems in Ukraine, official Web site of the National Bank of Ukraine. Available online. In: https://zakon.rada.gov.ua/laws/show/voo11500-20\#Text. Consultation date: 28/03/2021.

UKRAINE. 2021. Resolution of the Board of the National Bank of Ukraine 43, of May 19, 2021, on approval of the Regulation on information protection and cyber protection in payment systems. Official Web site of the National Bank of Ukraine. Available online. In: https://zakon.rada.gov.ua/laws/ show/vo043500-21\#Text. Consultation date: 28/03/2021.

UTEKA. 2018. TOP-5 international payment systems available for Ukrainians. Available online. In: https://uteka.ua/ua/publication/news-14-delovyenovosti-36-top-5-mezhdunarodnyx-platezhnyx-sistem-dostupnyx-dlyaukraincev. Consultation date: 28/03/2021.

VALVERDE, Santiago. AND KAHN, Charles. 2016. "Payment systems in the US and Europe: Efficiency, soundness and challenges". In: Estabilidad financiera. No. 30, pp. 11-33. Available online. In: https://www.bde.es/f/ webbde/GAP/Secciones/Publicaciones/InformesBoletinesRevistas/ RevistaEstabilidadFinanciera/16/MAYO\%202016/restfin2016301.pdf. Consultation date: $28 / 03 / 2021$. 
Vol. 39 N $^{\circ} 69$

Esta revista fue editada en formato digital y publicada en julio de 2021, por el Fondo Editorial Serbiluz, Universidad del Zulia. Maracaibo-Venezuela 